\title{
GANGGUAN ENDOKRIN PADA PASIEN THALASSEMIA $\beta$ MAYOR DI RSUP M DJAMIL PADANG
}

\author{
Shinta Ayudhia ${ }^{1}$, Eka Agustia Rini ${ }^{2}$ \\ Bagian Ilmu Kesehatan Anak, Fakultas Kedokteran Universitas Andalas/RSUP Dr. M. Djamil Padang \\ email: shintaayudhia@gmail.com
}

Submitted: 02-03-2020, Reviewer: 02-04-2020, Accepted: 05-04-2020

\begin{abstract}
Background. Endocrine disorders are a frequent complication in patients with major thalassemia affecting their quality of life. This complication occurs due to accumulation of iron in the body and involves organs such as endocrine gland so that patients can experience hypothyroidism, delayed puberty, short stature, insulin disorders, retarded bone age and osteoporosis. The aim of this study is to determine the incidence of endocrinopathy in patients of major thalassemia in RSUP M. Djamil Padang. Method. A prospective observational study of major thalassemia patients at DR M Djamil Hospital in January - April 2018. Data of serum ferritin, height, blood glucose, thyroid function, puberty status and bone age were performed. Data were analyzed by univariate and bivariate using Chi square test to find correlation between ferritin content with short stature, puberty status, bone age and osteoporosis, it is correlate if $p$ value $<0,05$. Data were analyzed using SPSS program. Results. There were 39 major thalassemia patients, 3 were refused, the mean age was $9.7 \pm 3.9$ years, 14 males (38.9\%), 22 females (61.1\%), duration of thalassemia 5, $6 \pm 4.0$ years. Short stature was observed in 28 patients $(77.8 \%)$, no patients suffering from hyperglycemia. Two people (5.6\%) had hypothyroidism, 4 of 6 were puberty $(66,67 \%)$ have delayed puberty. Retarded bone age was found in 16 people (44.4\%) and 3 people (8.3\%) had osteoporosis. There was no association between the levels of ferritin with short stature, puberty status, bone age and osteoporosis $(p=0.434, p=$ $0.601, p=0.839, p=1,000$ ) Conclusion. The most endocrine disorders in this study was short stature of 28 patients (77.8\%). There was no association between the levels of ferritin with short stature, puberty status, bone age and osteoporosis
\end{abstract}

Keywords : Endocrinopathy, Major thalassemia, feritin

Abstrak

Latar belakang. Gangguan endokrin merupakan komplikasi yang sering terjadi pada pasien thalassemia $\beta$ mayor yang berefek pada kualitas hidupnya. Komplikasi ini terjadi karena penumpukan besi di dalam tubuh dan melibatkan organ seperti kelenjar endokrin sehingga pasien dapat mengalami hipotiroid, pubertas terlambat, perawakan pendek, gangguan insulin, usia tulang terlambat dan osteoporosis. Tujuan dari penelitian ini adalah untuk mengetahui kejadian endokrinopati pada pasien thalassemia $\beta$ mayor di RSUP M Djamil Padang. Metode. Penelitian prospektif observasional terhadap pasien thalassemia $\beta$ mayor yang di RSUP DR M Djamil pada bulan Januari - April 2018. Dilakukan pengumpulan data kadar feritin serum, tinggi badan, gula darah sewaktu, fungsi tiroid, status pubertas dan bone age. Data dianalisis secara univariat dan bivariat dengan menggunakan uji Chi square untuk 
mencari hubungan antara kadar feritin dengan perawakan pendek, status pubertas, usia tulang dan osteoporosis, dikatakan berhubungan apabila $\mathrm{p}$ value $<0,05$. Data dianalisis dengan menggunakan program SPSS. Hasil. Didapatkan 39 pasien thalassemia $\beta$ Mayor, 3 orang menolak pemeriksaan, usia rata-rata 9,7 $\pm 3,9$ tahun, 14 laki-laki $(38,9 \%), 22$ perempuan $(61,1 \%)$, lama menderita thalasemia 5,6 $\pm 4,0$ tahun. Perawakan pendek ditemukan pada 28 pasien $(77,8 \%)$, tidak ada pasien yang menderita hiperglikemia. Dua orang $(5,6 \%)$ mengalami hipotiroid, 4 dari 6 orang usia pubertas $(66,67 \%)$ mengalami pubertas terlambat. Usia tulang retarded ditemukan pada 16 orang $(44,4 \%)$ dan 3 orang $(8,3 \%)$ mengalami osteoporosis. Tidak terdapat hubungan antara kadar feritin dengan perawakan pendek,status pubertas, usia tulang dan osteoporosis $(\mathrm{p}=0,434, \mathrm{p}=0,601, \mathrm{p}=0,839, \mathrm{p}=1.000)$. Kesimpulan. Gangguan endokrin terbanyak pada penelitian ini adalah perawakan pendek yaitu 28 pasien $(77,8 \%)$. Tidak terdapat hubungan antara kadar feritin dengan perawakan pendek, status pubertas, usia tulang dan osteoporosis

Kata kunci : Endokrinopati, thalassemia $\beta$ mayor, feritin

\section{LATAR BELAKANG}

Thalassemia $\beta$ mayor merupakan penyakit kelainan darah yang diturunkan secara genetik dimana tidak ada atau kurangnya sintesis rantai $\beta$ hemoglobin sehingga mengakibatkan gangguan produksi sel darah merah. ${ }^{1}$ Secara klinis pasien thalassemia $\beta$ mayor ditandai dengan anemia berat sehingga harus mendapat transfusi darah berulang. Transfusi darah berulang ini akan mengakibatkan penumpukan besi di beberapa organ seperti jantung, hati dan organ endokrin. Terapi kelasi besi bertujuan untuk mengurangi penumpukan besi. ${ }^{1,2}$ Walaupun pasien thalassemia $\beta$ mayor mendapatkan terapi kelasi besi secara teratur, prevalensi gangguan endokrin cukup tinggi, pada beberapa penelitian melaporkan mencapai $60 \%$. Gangguan endokrin dapat yang terjadi seperti perawakan pendek, pubertas terlambat, hipotiroid, dan gangguan insulin.2 Tujuan dari penelitian ini adalah untuk mengetahui profil endokrinopati pada pasien thalassemia $\beta$ mayor di RSUP $M$ Djamil Padang.

\section{METODE}

Dilakukan penelitian secara prospektif observasional terhadap 50 pasien thalassemia $\beta$ mayor di RSUP DR M Djamil pada bulan Januari - April 2018. Data yang diteliti adalah tinggi badan, status pubertas, kadar feritin serum, gula darah sewaktu, fungsi tiroid, status pubertas dan bone age.

Tinggi badan diukur dengan menggunakan microtoise. Pasien didiagnosis perawakan pendek apabila tinggi badan dibawah percentil 3 grafik Centers for Disease Control and Prevention 2000 Growth Chart (CDC 2000).

Status pubertas dinilai dengan metode Tanner. Pasien dikategorikan pubertas terlambat apabila belum ditemukan perkembangan payudara (M2) pada anak perempuan berusia 13 tahun atau lebih dan ukuran testis < 4ml (G2) pada anak laki-laki usia 14 tahun atau lebih.

$\begin{array}{cccc}\text { Fungsi } & \text { tiroid } & \text { dinilai } & \text { melalui } \\ \text { pemeriksaan } & \text { TSH, } & \text { FT4. } & \text { Pasien }\end{array}$
dikategorikan hipotiroid apabila kadar TSH meningkat dan FT4 menurun. Pemeriksaan 
bone age dilakukan untuk mengetahui usia tulang yang dibaca oleh ahli radiologi. Data dianalisis statistik dengan Pearson - Chi square untuk mencari hubungan antara kadar feritin dengan perawakan pendek, status pubertas dan usia tulang.

\section{HASIL}

Dari 50 orang pasien thalassemia hanya 39 penderita yang diteliti, 11 orang tidak datang, 3 orang menolak pemeriksaan. Karakterisiti pasien thalassemia dapat dilihat pada tabel dibawah ini.

\begin{tabular}{|c|c|c|}
\hline \multicolumn{3}{|l|}{$\begin{array}{l}\text { Tabel } 1 . \\
\text { Thalassemia }\end{array}$} \\
\hline Karakteristik & $\mathrm{n}$ & $\%$ \\
\hline Usia (Mean+SD/tahun) & $9,7 \pm 3,9$ & \\
\hline Lama Thalassemia & $5,6 \pm 4,04$ & \\
\hline (Mean \pm SD/tahun) & & \\
\hline \multicolumn{3}{|l|}{ Jenis Kelamin } \\
\hline Laki-laki & 14 & 38,9 \\
\hline Perempuan & 22 & 61,1 \\
\hline \multicolumn{3}{|l|}{ Kadar feritin } \\
\hline$<2500 \mathrm{ng} / \mathrm{ml}$ & 19 & 52,8 \\
\hline$>2500 \mathrm{ng} / \mathrm{ml}$ & 17 & 47,2 \\
\hline \multicolumn{3}{|l|}{ Hipotiroid } \\
\hline Ya & 2 & 5,6 \\
\hline Tidak & 34 & 94,4 \\
\hline \multicolumn{3}{|l|}{ Hiperglikemi } \\
\hline $\mathrm{Ya}$ & 0 & 0 \\
\hline Tidak & 36 & 100 \\
\hline \multicolumn{3}{|l|}{ Status pubertas } \\
\hline Delayed & 4 & 11,1 \\
\hline Pre pubertas & 30 & 83,3 \\
\hline Pubertas & 2 & 5,6 \\
\hline \multicolumn{3}{|l|}{ Usia tulang } \\
\hline Retarded & 16 & 44,4 \\
\hline Average & 20 & 55,6 \\
\hline \multicolumn{3}{|l|}{ Perawakan Pendek } \\
\hline $\mathrm{Ya}$ & 28 & 77,8 \\
\hline Tidak & 8 & 22,2 \\
\hline \multicolumn{3}{|l|}{ Osteoporosis } \\
\hline $\mathrm{Ya}$ & 3 & 8,3 \\
\hline Tidak & 33 & 91,7 \\
\hline
\end{tabular}

Dari tabel 1 disimpulkan usia rata-rata pasien thalassemia 9,7 $\pm 3,9$ tahun, paling banyak perempuan (61,1\%), lama menderita thalasemia $5,6 \pm 4,0$ tahun. Kelainan endokrin yang dtemukan paling banyak adalah perawakan pendek 28 pasien $(77,8 \%)$,

Gambaran kadar feritin dengan kelaian endokrin dapat dilihat pada tabel dibawah ini.

Tabel 2. Gambaran kadar feritin dengan hipotiroid, status pubertas, usia ulang, GDR, perawakan pendek dan osteoporosis.

\begin{tabular}{lllllll}
\hline $\begin{array}{l}\text { Kadar } \\
\text { Feritin }\end{array}$ & $\begin{array}{l}\text { Hipoti } \\
\text { roid }\end{array}$ & $\begin{array}{l}\text { Perawa } \\
\text { kan } \\
\text { pendek }\end{array}$ & $\begin{array}{l}\text { Usia } \\
\text { Tulang } \\
\text { retarde } \\
\text { d }\end{array}$ & $\begin{array}{l}\text { Puber } \\
\text { tas } \\
\text { terla } \\
\text { mabat }\end{array}$ & GDR & $\begin{array}{l}\text { Osteo } \\
\text { poros } \\
\text { is }\end{array}$ \\
\hline$<2500$ & 0 & 12 & 6 & 1 & 16 & 1 \\
& $(0 \%)$ & $(42,9 \%$ & $(37,5 \%$ & $(25 \%$ & $(44,4$ & $(33,3$ \\
& & ) & ) & ) & $\%)$ & $\%)$ \\
\hline$>2500$ & 2 & 16 & 10 & 3 & 20 & 2 \\
& $(100$ & $(57,1 \%$ & $(62,5 \%$ & $(75 \%$ & $(55,6$ & $(66,7$ \\
& $\%$ & ) & ) & ) & $\%)$ & $\%)$ \\
\hline
\end{tabular}

Dari tabel 2 disimpulkan semua pasien yang hipotiroid mempunyai kadar feritin $>2500$ $\mathrm{ng} / \mathrm{ml}$. Semakin tinggi nilai feritin maka angka kejadian perawakan pendek, usia tulang retarded, pubertas terlamabt dan osteoporosis juga tinggi. Dari semua pasien, ada 1 pasien yang mempunyai kadar feritin $>2500 \mathrm{ng} / \mathrm{ml}$ yang pendek, pubertas terlambat, usia tulang retarded dan osteoporosis.

\section{Tabel 3. Hubungan nilai feritin dengan} perawakan pendek

\begin{tabular}{llllll}
\hline Perawakan & \multicolumn{2}{l}{ Feritin } & \multicolumn{2}{l}{ p value } \\
\cline { 2 - 5 } Pendek & $<2500$ & \multicolumn{2}{l}{$>2500$} & \\
\cline { 2 - 5 } & $\mathrm{f}$ & $\%$ & $\mathrm{f}$ & $\%$ & \\
\hline Pendek & 12 & 70,6 & 16 & 84,2 & $\mathrm{p}=0,434$ \\
Tidak & 5 & 29,4 & 3 & 15,8 & \\
Pendek & & & & & \\
Jumlah & 17 & 100 & 20 & 100 & \\
\hline
\end{tabular}


Dari tabel 3 dapat disimpulkan 84,5\% pasien yang pendek memiliki kadar ferittin > 2500 $\mathrm{ng} / \mathrm{ml}$ dan tidak terdapat hubungan yang bermakna antara perawakan pendek dengan kadar feritin.

Tabel 4. Hubungan nilai feritin dengan status pubertas

\begin{tabular}{llllll}
\hline \multirow{2}{*}{$\begin{array}{l}\text { Status } \\
\text { Pubertas }\end{array}$} & \multicolumn{2}{l}{ Feritin } & \multicolumn{3}{l}{$\mathrm{p}$ value } \\
\cline { 2 - 5 } & \multicolumn{2}{l}{$<500$} & \multicolumn{2}{c}{$>2500$} & \\
\cline { 2 - 5 } & $\mathrm{f}$ & $\%$ & $\mathrm{f}$ & $\%$ & \\
\hline Delayed & 1 & 100 & 3 & 60 & $\mathrm{p}=601$ \\
Pubertas & 0 & 0 & 2 & 40 & \\
Jumlah & 1 & 100 & 5 & 100 & \\
\hline
\end{tabular}

Dari tabel 4 disimpulkan $60 \%$ pasien dengan pubertas terlambat memiliki kadar ferittin > $2500 \mathrm{ng} / \mathrm{ml}$ dan tidak terdapat hubungan yang bermakna antara status pubertas dengan kadar feritin.

Tabel 5. Hubungan nilai feritin dengan Usia tulang

\begin{tabular}{|c|c|c|c|c|c|}
\hline \multirow{3}{*}{$\begin{array}{l}\text { Usia } \\
\text { Tulang }\end{array}$} & \multicolumn{4}{|c|}{ Feritin } & \\
\hline & \multicolumn{2}{|c|}{$<2500$} & \multicolumn{2}{|c|}{$>2500$} & \\
\hline & \multicolumn{2}{|c|}{ f $\%$} & $\mathrm{f}$ & $\%$ & \\
\hline Retarded & \multicolumn{2}{|c|}{$6 \quad 42,9$} & 10 & 45,4 & \multirow[t]{3}{*}{$\mathrm{p}=839$} \\
\hline Normal & \multicolumn{2}{|c|}{$8 \quad 57,1$} & 12 & 54,6 & \\
\hline Jumlah & 14 & 100 & 22 & 100 & \\
\hline \multicolumn{6}{|c|}{$\begin{array}{l}\text { Dari tabel } 5 \text { disimpulkan bahwa } 57,1 \% \\
\text { pasien dengan usia tulang normal memilik } \\
\text { kadar feritin }<2500 \mathrm{ng} / \mathrm{ml} \text {. Tidak terdapat } \\
\text { hubungan yang bermakna antara usia tulang } \\
\text { dengan kadara feritin. }\end{array}$} \\
\hline \multicolumn{6}{|c|}{$\begin{array}{l}\text { Tabel 6. Hubungan nilai feritin dengan } \\
\text { Osteoporosis }\end{array}$} \\
\hline \multirow[t]{3}{*}{ Osteoporosis } & \multicolumn{4}{|c|}{ Feritin } & \multirow[t]{3}{*}{$\mathrm{p}$ value } \\
\hline & \multicolumn{2}{|c|}{$<2500$} & \multicolumn{2}{|c|}{$>2500$} & \\
\hline & $\mathrm{f}$ & $\%$ & $\mathrm{~F}$ & $\%$ & \\
\hline Osteoporosis & 1 & 5,6 & 2 & 11,1 & $\mathrm{p}=1,000$ \\
\hline Tidak & 17 & 94,4 & 16 & 88,9 & \\
\hline Jumlah & 18 & 100 & 18 & 100 & \\
\hline
\end{tabular}

Dari tabel 6 dapat disimpulkan bahwa $11,1 \%$ pasien yang osteoporosis memiliki kadar feritin $>2500 \mathrm{ng} / \mathrm{ml}$. Tidak terdapat hubungan yang bermakna antara osteoporosis dengan kadar feritin.

\section{DISKUSI}

Pada pasien thalassemia $\beta$ Mayor dapat terjadi penumpukan besi dalam darah dan beberapa organ. Penumpukan besi ini akan menurunkan produksi IGF-1 (somatomedin) dan menurunkan pertumbuhan kartilago tulang. Pada penelitian kami didapatkan 28 orang $(77,8 \%)$ mengalami perawakan pendek. Hasil penelitian ini hampir sama dengan dengan penelitian Soesanti dkk di Jakarta tahun 2012 yang mendapatkan perawakan pendek $65 \%,{ }^{3}$ Prevalensi perawakan pendek lebih sedikit ditemukan pada penelitian Arimbawa dan Ariawati yaitu $26 \%{ }^{4}$, Roth $d k k$ mendapatkan perawakan pendek $43,5 \% 5$. Perawakan pendek biasanya terjadi pada anak berusia diatas 10 tahun $(83,3 \%)$ dibandingkan dibawah 10 tahun $(16,7 \%)^{6}$. Shalitin $d k k$, Gomber dan Dewan serta Arimbawa dan Ariawati menggunakan kadar feritin 3000 ng/ml sebagai cut off point perawakan pendek adalah perawakan pendek. ${ }^{4,7,8}$ Pada penelitian ini cut off point perawakan pendek menggunakan kadar feritin 2500 $\mathrm{ng} / \mathrm{ml}$.

Pada pasien thalassemia $\beta$ Mayor seringkali mengalami pubertas terlambat akibat deposisis besi pada sel gonadotrop hipofisis. Pada penelitian ini 2 anak telah memasuki masa pubertas dan 6 orang pubertas terlambat. Roth $d k k$ menemukan 14 dari 18 pasien thalassemia mengalami pubertas terlambat ${ }^{5}$, hampir sama dengan 
penelitian Al Rimawi dkk melaporkan 17 dari 33 pasien thalassemia mengalami pubertas terlambat. ${ }^{9}$ Kadar feritin serum yang tinggi mempengaruhi kematangan seksual sehingga dapat digunakan sebagai prediktor gangguan pubertas pada pasien thalassemia, seperti penelitian Shalitin $d k k$ yang melaporkan rerata kadar feritin 2500 ng/ml sebagai cut off point selama pre pubertas. ${ }^{7}$ Pada penelitian ini 3 dari 4 orang yang mengalami pubertas terlambat memiliki kadar feritin lebih dari $2500 \mathrm{ng} / \mathrm{ml}$. Semua pasien yang mengalami pubertas terlambat memiliki perawakan yang pendek.

Hasil pemeriksaan bone age menunjukkan 16 orang pasien mengalami usia tulang yang terlambat, 14 orang diantaranya perawakan pendek. Semua pasien yang mengalami pubertas terlambat menunjukkan usia tulang yang terlambat juga. Tidak terdapat hubungan antara kadar feritin dengan defisit usia tulang. Hasil penelitian ini hampir sama dengan penelitian Andayani $d k k$ yang melaporkan tidak terdapat hubungan signifikan antara kadar feritin dengan defisit usia tulang, namun terdapat hubungan antara usia anak dan defisit usia tulang.

\section{DAFTAR PUSTAKA}

1. Run D, Rachmilewitz E. $\beta$-Thalassemia. N Engl J Med 2005;1135-46.

2. Saxena A. Growth Retardation in thalassemia major patients. Int J Hum Genet 2003;3:237-46.

3. Soesanti F, Putriasih SA, Pulungan A, Wahidayat PA. Endocrinopathies in thalassemia major patients in thalassemia center Jakarta, Indonesia. 7th APPES Biennial Scientific Meeting. 2012
4. Arimbawa M, Ariawati K. Profil pertumbuhan, hemoglobin pre-transfusi, kadar feritin, dan usia tulang anak pada thalassemia mayor. Sari pediatri. 2011;13(4):299- 304

5. Roth C, Pekrun A, Bartz M, Jarry H, Eber S, Lakomek M, dkk. Short stature and failure pubertal development in thalassemia major: evidence for hypothalamic neurosecretory dysfunction of growth hormone secretion and defective pituitary gonadotropin secretion. Eur J Pediatrics 1997;156:77783.

6. Hamidah A, Rahmah R, Azmi T, Aziz J, Jamal R. Short stature and truncal shortening in transfusion dependent thalassemia patients: results from a thalassemia center in Malaysia. Southeast As J Trop Med Public Health 2001;32:625-30.Haliloglu B, Tuysuz G, Tayfun F. Endocrinopathies in Turkish children with thalassemia major. J Pediatr res. 2017;4(4):216-9

7. Shalitin S, Carmi D, Weintrob N, Phillip M, Miskin H, Kornreich L, dkk. Serum ferritin level as a predictor of impaired growth and puberty in thalassemia major patients. Eur J Haematol 2005;74:93-100

8. Gomber S, Dewan P. Physical growth patterns and dental caries in thalassemia. Indian Pediatr 2006;43:1064-9.

9. Al-Rimawi HS, Jallad MF, Amarin ZO, Al Sakaan R. Pubertal evaluation of adolescent boys with $\beta$-thalassemia major and delayed puberty. Fertility and Sterility 2006;86:886-90.

10. Andayani SH, Sekarwana N, Fadil R. Association between age and serum 
ferritin level with bone age deficit in children with thalassemia major. Paediatr Indones 2008;48:33-6.

11. Pramita D, Batubara JRL. Pubertas terlambat pada thalassemia mayor. Sari pediatri. 2003;5(1):4-11 